\title{
The assessment of the influence of temperature differences in individual ducts of an intake manifold on the unevenness of air filling in a cylinder of a combustion engine
}

\begin{abstract}
The paper presents the issues related to the unevenness of air filling inside a cylinder of a combus-tion engine. In order to evaluate such an unevenness a test stand and simulation models have been built. The tests stand allows a full assessment of the influence of selected parameters on the uneven-ness of the filling process. In this case the deviations in individual ducts of an intake manifold have been analyzed. This variant has been repeated in simulation tests, where concentrated models have been used for the description of the phenomena. The tests have shown an approximately 6\% influence of a $64^{\circ} \mathrm{C}$ temperature deviation on the unevenness of the cylinder filling. The simulation tests have not shown a significant impact of the thermal state on the filling process.
\end{abstract}

Key words: combustion engines, intake manifold, unevenness of cylinder filling

\section{Ocena wpływu zróżnicowania temperatury przewodów kolektora dolotowego na nierównomierność napełniania powietrzem cylindrów silnika spalinowego}

\begin{abstract}
W artykule przedstawiono problematyke nierównomierności napetniania powietrzem cylindrów silnika spalinowego. $W$ celu oceny tej nierównomierności zbudowano stanowisko badawcze oraz modele symulacyjne. Stanowisko umożliwia kompleksowq ocenę wpływu wybranych parametrów na nierównomierność napetniania. W tym przypadku analizie poddano zróżnicowanie temperatury przewodów kolektora dolotowego. Ten wariant powtórzono w badaniach symulacyjnych, gdzie do opisu zjawisk wykorzystano modele skupione. Badania doświadczalne wykazały ok. 6-procentowy wplyw $64^{\circ} \mathrm{C}$ zróżnicowania temperatury na nierównomierność napetniania cylindrów silnika. Natomiast badania symulacyjne nie wykazały znaczacego wplywu stanu cieplnego na proces napetniania.
\end{abstract}

Słowa kluczowe: silnik spalinowy, układ zasilania, nierównomierność napetniania

\section{Introduction}

Multi cylinder high speed positive ignition combustion engines are characterized by difference in the operation of individual cylinders $[9,10]$. This may cause irregular engine operation and elevated emissions which results in difficulties maintaining the external parameters on a required level.

Out of many factors influencing the variations in individual cylinder operation the following are the most important:

- composition of the air fuel mixture in individual cylinders represented by the air excess coefficient $\lambda_{i}{ }_{i}^{1)}$,

- amount of air fuel mixture in individual cylinders represented by the filling coefficient $\eta_{\mathrm{v}}$,

- air tightness of the cylinders represented by the pressure drop $\Delta \mathrm{p}_{\mathrm{i}}$,

- energy and ignition angle,

- valve timing,

- precision of workmanship.

Based on the analysis of literature the first two factors can be seen as the most significant i.e. the composition and amount of air fuel mixture in individual cylinders, which, to a large extent depend on the preparation and delivery of the mixture in the manifold.

1) The $\mathrm{i}$ index signifies indexes of $\mathrm{i}$-cylinder in a c-cylinder engine, $i \in\{1, \ldots, c\}$.

\section{Wstęp}

Wielocylindrowe szybkobieżne silniki spalinowe o zapłonie iskrowym cechują zauważalne różnice w pracy poszczególnych cylindrów $[9,10]$. Może powodować to nierównomierność ich biegu i podwyższone stężenie toksycznych składników spalin, a co za tym idzie, trudności z utrzymaniem wskaźników zewnętrznych na żądanym poziomie.

Spośród wielu czynników mających wpływ na zróżnicowanie pracy poszczególnych cylindrów do najważniejszych można zaliczyć:

- rodzaj składu mieszaniny paliwowo-powietrznej w poszczególnych cylindrach silnika reprezentowany przez współczynnik nadmiaru powietrza $\lambda_{i}^{1)}$,

- ilość mieszaniny paliwowo-powietrznej w poszczególnych cylindrach reprezentowaną przez współczynnik napełnienia $\eta_{\mathrm{vi}}$,

- szczelność cylindrów reprezentowaną przez spadek ciśnienia $\Delta \mathrm{p}_{\mathrm{i}}$,

- energię i kąt wyprzedzenia zapłonu,

- fazy rozrządu,

- dokładność wykonania.

$\mathrm{Na}$ podstawie analizy literatury za najbardziej istotne można uznać dwa pierwsze czynniki, tj, skład i ilość miesza-

\footnotetext{
1) Indeksem i oznaczono wskaźniki dotyczące i-tego cylindra w c-cylindrowym silniku, $i \in\{1, \ldots, c\}$.
} 
The selection of the intake manifold system in terms if its geometry (length, diameter) or factors such as temperature, wall smoothness etc. still remains an issue. In the course of optimization, the main criteria are the flow resistance and the wave phenomena related to the vibration of the medium in the intake system, which is then reflected in the filling level of individual cylinders. Despite very advanced software and the creation of more and more complex mathematical models only the prototype tests will decide about the final design of the system. The main reason for such a state can be the imperfection of the model i.e. a certain level of simplification in the mathematical model for each case.

\section{Subject of the research}

The subject of the research were the processes accompanying the cylinder filling in a piston combustion engine. The main stress was put on the air flow while the local temperatures in the intake manifold varied. In the course of the investigation, the impact of the exhaust manifold on the cylinder filling process was omitted, which, according to the literature $[2,6,11]$, is four times smaller than the impact of the processes in the intake manifold.

In order to investigate the said processes, necessary became a selection of such an object of the research that would allow a generalization and transposing of the results onto other objects i.e. characterized by a typical mechanical and material design. Based on the analysis of the technical niny paliwowo-powietrznej w poszczególnych cylindrach, co wynika w dużej mierze $\mathrm{z}$ procesu przygotowania i transportowania mieszaniny palnej w układzie dolotowym silnika.

Problematycznym zagadnieniem pozostaje nadal dobór układu dolotowego pod względem geometrii, tzn. jego długości, średnicy, jak też wpływu czynników, takich jak temperatura, chropowatość ścianek itd. W toku optymalizacji za główne kryteria uznaje się opory przepływu oraz wykorzystanie efektów falowych związanych z drganiami czynnika w układzie dolotowym, co znajduje odwzorowanie w stopniu napełnienia poszczególnych cylindrów. Pomimo bardzo zaawansowanego oprogramowania i tworzenia coraz to bardziej złożonych modeli matematycznych, dopiero badania prototypowe rozstrzygają o tym, jaki ostatecznie ma być układ. Za główną przyczynę tego stanu rzeczy można uznać każdorazowy stopień uproszczeń w modelu matematycznym, czyli pewną jego niedoskonałość.

\section{Przedmiot badań}

Przedmiotem badań były procesy towarzyszące napełnianiu powietrzem cylindrów tłokowego silnika spalinowego. Główny nacisk położono na przepływ powietrza, gdy zróżnicowane są lokalne temperatury w układzie dolotowym. Pominięto w toku badań identyfikacyjnych wpływ układu wylotowego na proces napełniania, który zgodnie $\mathrm{z}$ doniesieniami literaturowymi $[2,6,11]$ jest około czterokrotnie mniejszy niż wpływ zjawisk w układzie dolotowym.

Table 1. Basic technical data of the tested engine

Tabela 1. Podstawowe dane techniczne badanego silnika

\begin{tabular}{|c|c|c|c|}
\hline Work cycle/Cykl pracy & \multicolumn{3}{|c|}{ Positive ignition, 4 stroke/o zapłonie iskrowym, 4-suwowy } \\
\hline Number and arrangement of cylinders/Liczba i układ cylindrów & \multicolumn{3}{|c|}{4 in-line, vertical/4 w rzędzie, pionowo } \\
\hline Fueling system/Uktad zasilania paliwem & \multicolumn{3}{|c|}{ Multipoint injection/wtrysk wielopunktowy } \\
\hline Air-fuel mixture adjustment/Regulacja składu mieszaniny paliwowo-powietrznej & \multicolumn{3}{|c|}{$\begin{array}{l}\text { Short term adjustment (oxygen sensor)/korekcja krótkookre- } \\
\text { sowa (czujnik obecności jonów wolnego tlenu w spalinach) }\end{array}$} \\
\hline Cylinder bore/Średnica cylindrów [mm] & \multicolumn{3}{|c|}{77} \\
\hline Piston stroke/Skok tłoka $[\mathrm{mm}]$ & \multicolumn{3}{|c|}{79,5} \\
\hline Displacement/Pojemność skokowa $\left[\mathrm{dm}^{3}\right]$ & \multicolumn{3}{|c|}{1481} \\
\hline Compression ratio/Stopień sprężania & \multicolumn{3}{|c|}{9} \\
\hline Maximum power@rpm/Moc maksymalna/przy prędkości obrotowej & Acc. to DIN/wg DIN & $52,5 / 6250$ & $\mathrm{~kW} /(\mathrm{rpm})$ \\
\hline Maximum torque@rpm/Maksymalny moment obrotowy/przy prędkości obrotowej & Acc. to DIN/wg DIN & $118 / 3250$ & $\mathrm{~N} \cdot \mathrm{m} /(\mathrm{rpm})$ \\
\hline
\end{tabular}

data the subassemblies of a 4 cylinder four stroke 1500 $\mathrm{cm} 3$ positive ignition engine by FSO has been selected. This engine belongs to a group of the most common single cylinder displacement. The basic technical data of the tested and described engine have been presented in Table 1.

\section{Research methodology}

The analysis of the influence of the thermal state of the intake manifold on the unevenness of the cylinder air filling was performed on a specially designed tests stand (Fig. 1) as per the guidelines set forth in [8]. The research methodology consists in determining of the dynamic characteristics of the filling process of the measurement tanks. En route to the measurement tanks an intake manifold is installed and the
Ażeby możliwe było zbadanie przedmiotowych procesów, niezbędne stało się wskazanie takiego obiektu badań, który umożliwi uogólnienie wyników na inne obiekty, a więc charakteryzującego się typową konstrukcją tak w aspekcie struktury mechanicznej, jak i materiałowej. Na podstawie analizy danych technicznych wybrano podzespoły 4-cylindrowego, czterosuwowego silnika o zapłonie iskrowym, produkcji FSO ${ }^{2)}$, o objętości skokowej $1500 \mathrm{~cm}^{3}$. Silnik ten wchodzi w skład grupy z najczęściej spotykaną na naszym rynku objętością skokową jednego cylindra. Podstawowe dane techniczne silnika poddanego badaniom doświadczalnym i opisowi modelowemu podano w tab. 1.

2) Silnik ten w późniejszych wersjach występował jako DAEWOO-FSO. 
flow is additionally distorted by the valve timing system. The recorded characteristics is a response to a unitary step function and the external stimulus that triggers the flow is the difference in static pressures at the moment of initiation. Currently, this method is successfully applied in the testing of pneumatic elements of brake systems $[4,5]$. The question of the difference in pressures being the stimulus for the flow initiation has, so far, been open (as far as the engine tests are concerned). In [12] an in-depth analysis of this problem has been presented, supported not only by literature but also own research on test stands (dynamic conditions).

The basic elements of the test stand are: engine block, cylinder head, aggregates, electrical drive of the timing system, extraction and control systems, cut-off valve, measurement tanks and the measurement kit. A step function was obtained through a specially designed system that ensured repeatability of the initiation of the measurement as well as a smooth air acquisition into the intake ducts.

\section{Metodyka badań}

Analizę wpływu stanu cieplnego układu dolotowego na nierównomierność napełnienia cylindrów powietrzem przeprowadzono na specjalnie do tego celu skonstruowanym stanowisku (rys. 1), zgodnie z wytycznymi przedstawionymi w [8]. Metoda badań polega na wyznaczeniu charakterystyki dynamicznej procesu napełniania powietrzem zbiorników pomiarowych, gdzie na drodze przepływu znajduje się układ dolotowy, dodatkowo przepływ zakłócony jest częstością działania układu rozrządu. Zarejestrowana charakterystyka jest odpowiedzią na wymuszenie jednostkową funkcją skokową, zaś bodźcem zewnętrznym wywołującym przepływ jest różnica ciśnień statycznych w chwili startu. Metoda ta jest obecnie $\mathrm{z}$ powodzeniem stosowana $\mathrm{w}$ badaniach elementów pneumatycznych układów hamulcowych [4, 5]. Sprawą otwartą (w przypadku badań silnikowych) pozostawała różnica ciśnień stanowiąca bodziec zewnętrzny wywołujący przepływ. W [12] przedstawiono głęboką analizę tego pro-

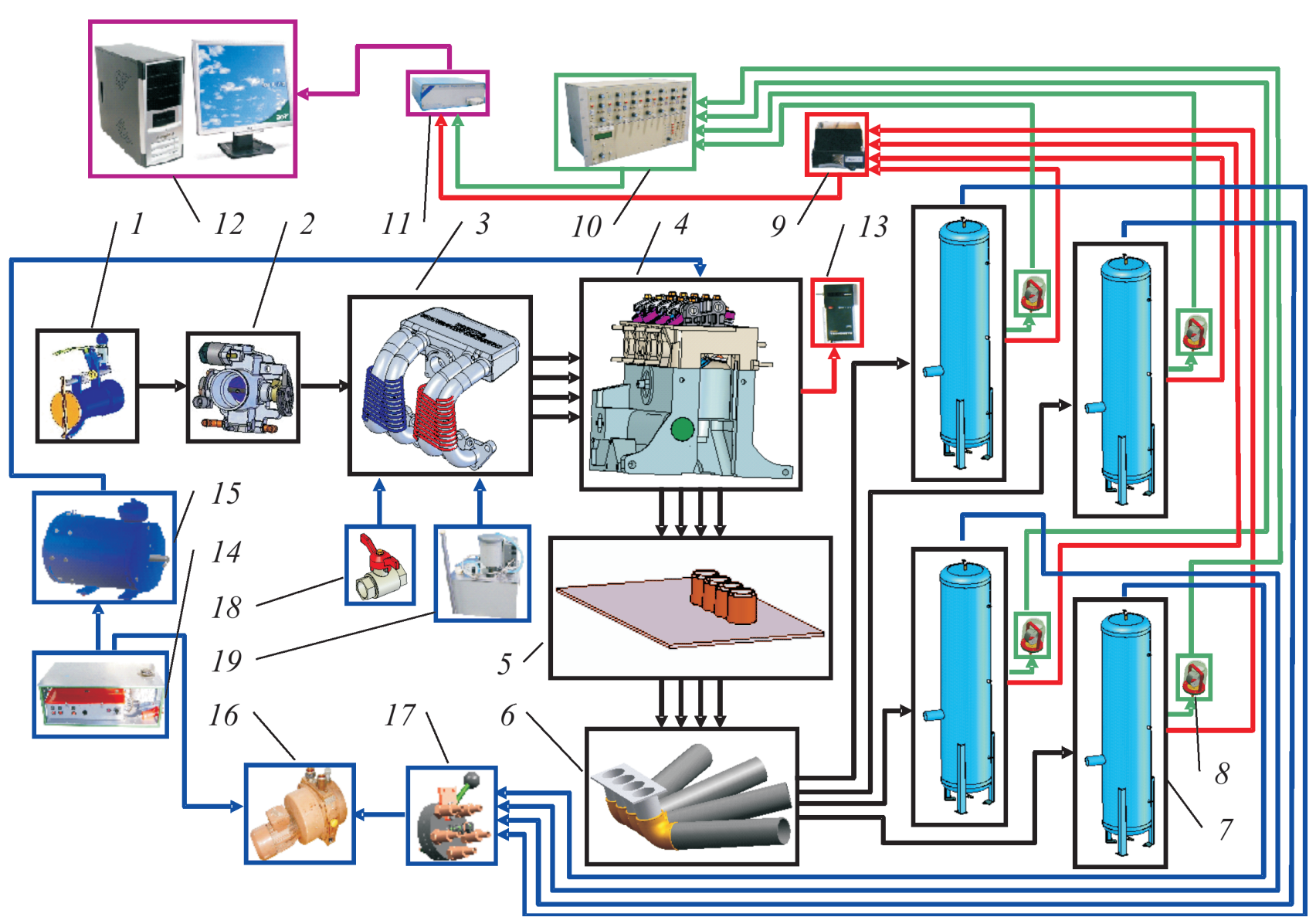

Fig. 1. Schematics of the test stand: 1 - intake duct closure, 2 - throttle subassembly, 3 - intake manifold, 4 - engine block with cylinder head, 5 - support with spacers, 6 - exhaust manifold, 7 - measurement tank, 8 - pressure sensor, 9 - temperature measurement kit 4 x CL62K with NiCr-NiAl thermocouples, 10 - tensometric bridge CL external, 11 - measurement sheet MC 201, 12 - desktop with software for MC 201 card, 13 - multitachograph PRLT - 10 photoelectric sensor, 14 - control system, 15 - direct current motor, 16 - vacuum pump with a drive, 17 - multivalve, 18 - cold water supply system (utility from the building), 19 - hot water supply system (Thermostat U10)

Rys. 1. Schemat stanowiska badawczego: 1 -zamknięcie traktu dolotowego, 2 - podzespót przepustnicy, 3 - kolektor dolotowy, 4 - blok silnika wraz z głowica, 5 - blat z tulejami dystansowymi, 6-kolektor odprowadzajacy, 7 -zbiornik pomiarowy, 8 - czujnik ciśnienia, 9 - zestaw do pomiaru temperatur 4 x CL62K z termoparami NiCr-NiAl, 10 - mostek tensometryczny CL ZEWN, 11 - karta pomiarowa MC 201, 12 - komputer PC z oprogramowaniem karty MC 201, 13 - multitachometr PRLT - 10 wraz z czujnikiem fotoelektrycznym, 14 - układ sterowania, 15 - silnik pradu stałego, 16 - pompa podciśnieniowa wraz z napędem, 17 - wielozawór, 18 - układ zasilania $w$ wodę zimna (instalacja medialna budynku), 19 - układ zasilania w wode goraca (wykorzystujacy Termostat U10) 
In order to diversify the temperatures of the walls of the intake manifold two separate spirals were built (Fig. 1) tightly braiding the intake ducts ${ }^{2}$. The spirals of the ducts of the I and II cylinder were supplied with tap water (the circulation is forced by the operating pressure of the water supply system - minimum temperature $14^{\circ} \mathrm{C}$ ), spiral of the III and IV cylinder used the heating system through a thermostat U10 (circulation forced adjustable in three ranges- maximum temperature $100^{\circ} \mathrm{C}$ ).

The influence of the temperature deviations in the intake manifold on the unevenness is omitted or treated as insignificant in many publications. Hence, it was necessary to take this into consideration during the investigation. In order to verify the issues, it was necessary to plan the experiment in such a way that would answer the question whether the input quantity (temperature differences in the intake manifold) has an impact on the object of the investigation. As far as the second input quantity is concerned - engine speed - we have certainty basing our judgment on the results obtained by Rawski (1999).

In the course of the experiment, a randomized complete block design plan was assumed serving as an instrument for the verification of the significance of the influence of the input quantities on the output quantity. The case of two input quantities with a preset division of influence is reflected in such plans.

By a discretization of the engine speed through a six term sequence and changing two temperature distributions (this resulted from the expected miniscule impact - hence, linear dependence) a level of air supply evenness was determined $\theta \mathrm{R}$. Taking into consideration the plan PS/RB-C ${ }^{3)}, 12$ samples were made (experimental units) and each of the units equaled the arithmetic average of a given number of repeats. The results of the measurements were verified through a Student Test using comparison of rows (depending on $n$ ) of the arithmetic averages.

\section{Results and analysis}

The obtained dynamic characteristics could have been analyzed as per the procedures given in [8], the there presented method focused on discussing a selected point in the dynamic characteristic not giving full information on the course of the experiment as a whole. Hence, the authors decided to determine such a parameter of flow that would be adequate for the whole course.

Tentatively, certain simplifications were assumed such as the isentropic flow in the intake system in an adiabatic partition where the dependence related to the mass air stream flowing through a generalized local resistance can be noted in the following manner:

$$
\dot{\mathrm{m}}=(\mu \mathrm{A}) \frac{\mathrm{p}_{\mathrm{a}}}{\mathrm{RT}_{\mathrm{a}}} \mathrm{v}_{\max } \varphi_{\max }(\sigma) \mathrm{r}(\sigma)
$$

\footnotetext{
2) This type of manifold has ducts connected in pairs 1-2 and 3-4,which enhanced the temperature difference.

3) Randomized Compete Block Design, CB-design in short.
}

blemu, popartą nie tylko doniesieniami literaturowymi, ale także badaniami własnymi, m.in. na hamowni podwoziowej (w warunkach dynamicznych).

Podstawowymi elementami stanowiska są m.in. blok silnika wraz z głowicą i osprzętem, elektryczny napęd rozrządu, układ wysysania wraz z układem sterowania, zawór odcinający, zbiorniki pomiarowe oraz zestaw pomiarowy. Wymuszenie jednostkową funkcją skokową uzyskiwano przez specjalnie do tego celu skonstruowany układ zapewniający powtarzalność startu pomiarów, a także umożliwienie „łagodnego” wlotu powietrza do traktu dolotowego.

W celu zróżnicowania temperatur ścianek przewodów kolektora dolotowego wykonano dwie odizolowane spirale (rys. 1) szczelnie oplatające pary przewodów dolotowych ${ }^{3)}$. Spirale przewodów I i II cylindra zasilane były wodą z instalacji medialnej budynku (obieg wymuszony ciśnieniem tam panującym - temperatura minimalna $14^{\circ} \mathrm{C}$ ), z kolei spirale III i IV cylindra wykorzystywały układ grzania w postaci termostatu U10 (obieg wymuszony z możliwością regulacji $\mathrm{w}$ trzech zakresach - temperatura maksymalna $100^{\circ} \mathrm{C}$ ).

Wpływ zróżnicowania temperatury przewodów kolektora dolotowego na równomierność zasilania silnika jest w wielu publikacjach pomijany lub traktowany jako mało istotny. Dlatego też należało to uwzględnić w planowaniu doświadczenia. Aby zweryfikować te zagadnienia, konieczne było przyjęcie takiego planu eksperymentu, który odpowiadałby na pytanie, czy wielkość wejściowa, jakąjest zróżnicowanie temperatur przewodów kolektora dolotowego, ma wpływ na obiekt badań. Co do drugiej wielkości wejściowej - prędkości obrotowej - mamy pewność, opierając się na wynikach otrzymanych przez Rawskiego (1999).

W toku doświadczenia przyjęto kompletny plan randomizowany blokowy, który służy przede wszystkim do weryfikacji istotności wpływu wielkości wejściowych na wielkość wyjściową. Przypadek dwóch wielkości wejściowych, z założonym z góry podziałem wpływów, znajduje odzwierciedlenie w tego typu planach.

Dyskretyzując sześciowyrazowym ciąiem prędkość obrotową i jednocześnie zmieniając dwa rozkłady temperatur (wynikało to ze spodziewanego niewielkiego wpływu - stąd zależność liniowa), wyznaczono stopień równomierności zasilania powietrzem $\theta \mathrm{R}$. Uwzględniając zastosowanie planu PS/RB-C ${ }^{4}$, wykonano 12 próbek (jednostek doświadczalnych), przy czym każda z jednostek doświadczalnych odpowiadała średniej arytmetycznej z określonej liczby powtórzeń. Wyniki pomiarów zweryfikowano za pomocą testu Studenta, korzystając z porównania wierszami (zależnie od n) średnich arytmetycznych.

\section{Wyniki badań $i$ ich analiza}

Otrzymane charakterystyki dynamiczne mogły być poddawane analizie zgodnie $\mathrm{z}$ procedurami przedstawio-

\footnotetext{
3) Ten rodzaj kolektora dolotowego ma na pewnym odcinku parami 1-2 i 3-4 połączone przewody, co dodatkowo sprzyjało zróżnicowaniu temperatury.

4) $\mathrm{Z}$ angielskiego - Randomized Compete Block Design, czyli w skrócie CB-design.
} 
We can note the change in the air pressure in the measurement tank as follows:

$$
\frac{d p_{z}}{d t}=\frac{\kappa R}{V_{z}}\left(T_{a} \dot{m}-\frac{\alpha F_{z}(\kappa-1)}{k R}\left(T_{z}-T_{s}\right)\right)
$$

where: $p_{a}$ - atmospheric pressure, $p_{z}$ - pressure in the measurement tank, $\mathrm{V}_{\mathrm{z}}$ - measurement tank volume, $\mathrm{F}_{\mathrm{z}}$ - area taking part in the heat exchange with the flowing air, $(\mu \mathrm{A})-$ conductance (throughput), $\mathrm{T}_{\mathrm{a}}$ - ambient temperature, $\mathrm{T}_{\mathrm{z}}$ - air temperature in the measurement tank, $T_{s}$ - temperature of the walls of the measurement tank, $\mathrm{R}$ - gas constant, $\mathrm{v}_{\mathrm{m}}$ - sound propagation in a stationary gas, $\kappa$ - adiabate exponent, $\varphi_{\max }(\sigma)$ - maximum value of the St' Venant and Wantzel function, $\varphi(\sigma)$ - dimensionless flow function, $\alpha-$ heat penetration coefficient in the flowing gas.

By extending the system to this composed of: four cylinders, intake manifold with a common volume and a throttle we shall obtain a schematics for the mathematical description (Fig. 2).

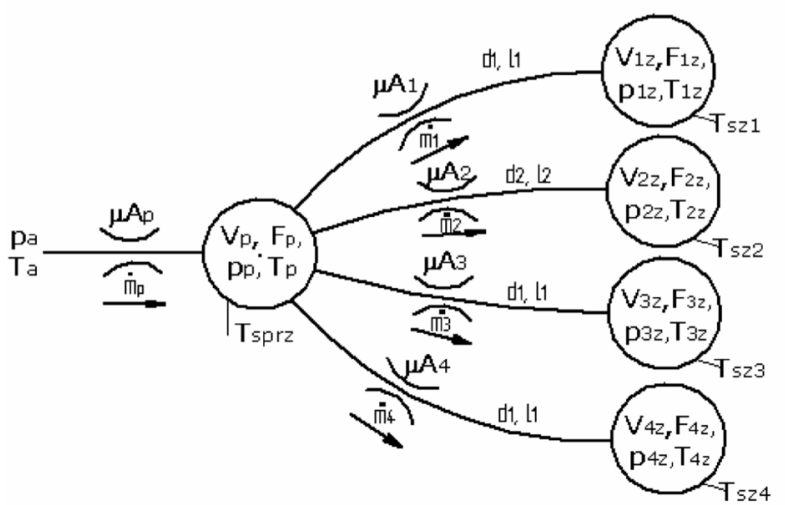

Fig. 2. Schematics presenting the assumed model of flow in the model test stand conditions for identification purposes

Rys. 2. Schemat przedstawiajacy przyjety model przeptywu $w$ warunkach stanowiska modelowego do celów identyfikacyjnych

Based on this schematics we can form an array of differential equations (3), using the method of nodes [4], located in concentrated volumes.

Through a proper selection of conductance ${ }^{4}(\mu \mathrm{A})_{1 \ldots 4}$ we can obtain a high level of experimental and test course conformity (Fig. 3). Knowing the conductance allows a characterization of the local resistance valid for the whole analyzed range. The process of air flow through the intake system is a complex and difficult phenomenon to describe in mathematics. The distortion in the form of a cyclic timing system operation additionally causes wave phenomena. Hence, assuming identical duct geometry $(\mu \mathrm{A})_{i}$ in this case a variability of the throughput of the intake ducts has been adopted (resulting from the wave phenomena and thermal state difference).

\footnotetext{
4) The throughput was determined by the conductance.
}

nymi w [8], lecz metoda tam zaprezentowana skupiała się na poddaniu dyskusji wybranego punktu charakterystyki dynamicznej, nie dając pełnej informacji o całym przebiegu badań. Dlatego zdecydowano się wyznaczać taki parametr przepływu, który będzie obowiązywał w odniesieniu do całego przebiegu.

Wstępnie przyjęto pewne uproszczenia, zakładając, że przepływ w układzie dolotowym będzie izentropowy w osłonie adiabatycznej, przy którym zależność na masowy strumień powietrza przepływającego przez uogólniony opór miejscowy, można zapisać jako (1).

Zmianę ciśnienia powietrza $\mathrm{w}$ zbiorniku pomiarowym zapisujemy jako (2),

gdzie: $p_{a}-$ ciśnienie atmosferyczne, $p_{z}$ - ciśnienie $w$ zbiorniku pomiarowym, $\mathrm{V}_{\mathrm{z}}$ - objętość zbiornika pomiarowego, $\mathrm{F}_{\mathrm{z}}$ - pole powierzchni biorące udział $\mathrm{w}$ wymianie ciepła $\mathrm{z}$ przepływającym powietrzem, $(\mu \mathrm{A})$ - konduktancja (przepustowość), $\mathrm{T}_{\mathrm{a}}$ - temperatura powietrza otaczającego, $\mathrm{T}_{\mathrm{z}}$ - temperatura powietrza w zbiorniku pomiarowym, $\mathrm{T}_{\mathrm{s}}$ - temperatura ścianek zbiornika pomiarowego, $\mathrm{R}$ - stała gazowa, $\mathrm{v}_{\mathrm{m}}$ - prędkość rozchodzenia się dźwięku w nieruchomym gazie, $\kappa$ - wykładnik adiabaty, $\varphi_{\max }(\sigma)$ - wartość maksymalna funkcji St' Venanta i Wantzela, $\varphi(\sigma)$ - bezwymiarowa funkcja przepływu, $\alpha$ - współczynnik wnikania ciepła w przepływającym gazie.

Rozbudowując układ do 4 cylindrów kolektora dolotowego z objętością wspólną i przepustnicą, otrzymamy ostatecznie schemat służący do opisu matematycznego (rys. 2).

Na podstawie tego schematu można napisać układ równań różniczkowych (3), wykorzystując metodę węzłów [4], przy ich położeniu w objętościach skupionych.

Przez odpowiedni dobór konduktancji ${ }^{5)}(\mu \mathrm{A})_{1 \ldots 4}$ można otrzymać dużą zgodność przebiegów eksperymentalnych i doświadczalnych (rys. 3). Znajomość konduktancji pozwala na scharakteryzowanie oporu miejscowego obowiązującego w całym badanym zakresie. Proces przepływu powietrza przez układ dolotowy jest złożony i trudny w opisie matematycznym. Zakłócenie w postaci cyklicznego działania układu rozrządu powoduje dodatkowo wystąpienie zjawisk falowych. Stąd też, w tym przypadku, przyjęto, przy założeniu tej samej geometrii przewodów dolotowych, zmienność ich przepustowości $(\mu \mathrm{A}) \mathrm{i}$, będącą wynikiem oddziaływania zjawisk falowych i zróżnicowania stanu cieplnego jako (3).

$\mathrm{m}_{1 \ldots 4}$ analogicznie do (1).

W pracy [12] poddano porównaniu różne funkcje natężenia przepływu. Po wnikliwej analizie ostatecznie uznano za najbardziej miarodajną (tj. charakteryzującą się najmniejszym błędem średnim i maksymalnym) funkcję Miatluka-Avtuszko (4) ze zmienionym parametrem a $=1,07^{6}$ ) [4], którą w skrajnym przypadku charakteryzował 7-krotnie mniejszy błąd średni niż permanentnie stosowaną funkcję St’ Venanta i Wantzela określony jako (4).

W poszukiwaniach konduktancji wykorzystano metodę regresji nieliniowej, minimalizując wskaźnik FPE1 (5). Mi-

\footnotetext{
${ }^{5)}$ Konduktancją określono przepustowość.

6) Oryginalnie wartość $\mathrm{a}=1,13$.
} 

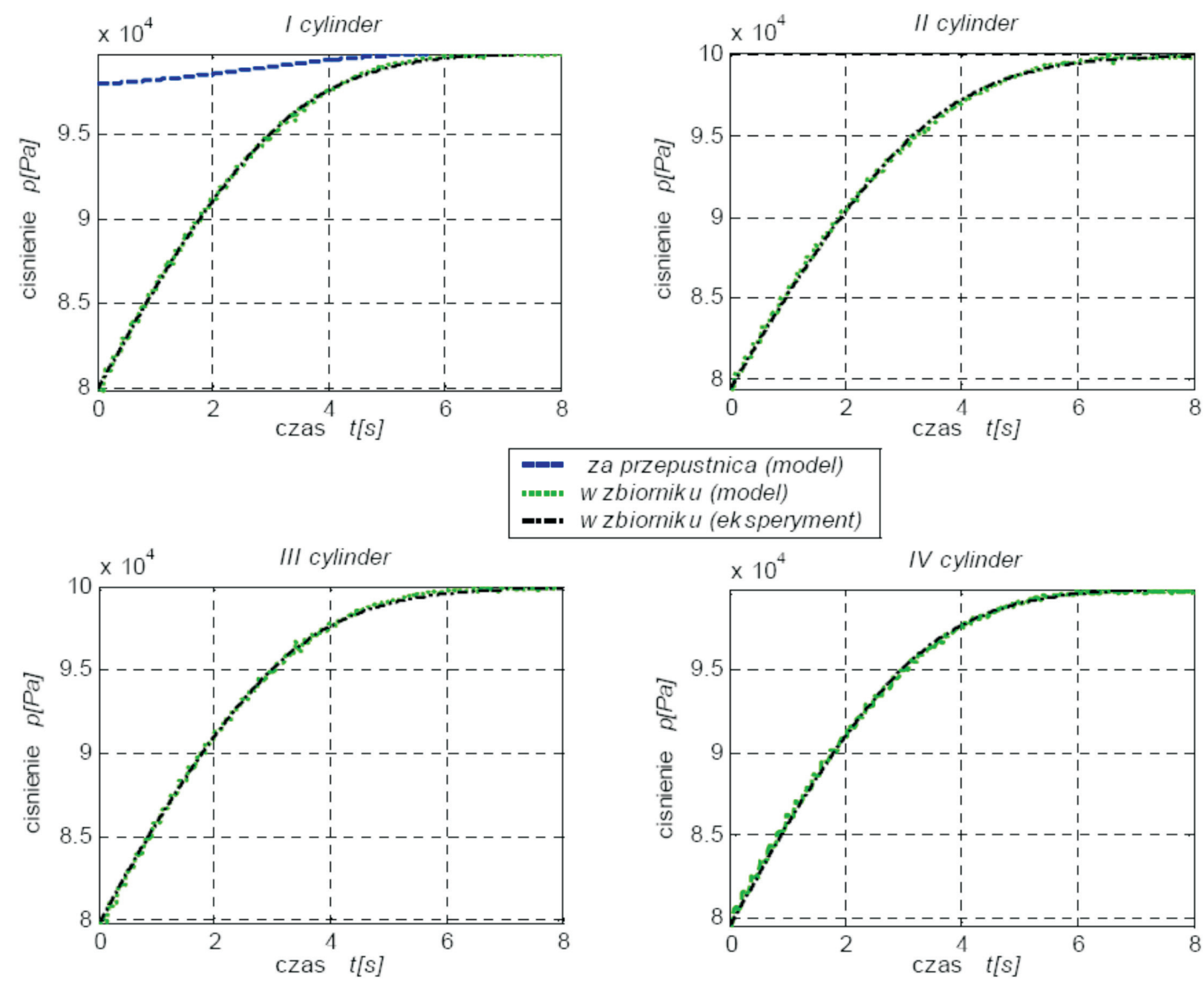

Fig. 3. Example comparison of the experimental courses with the model ones at $\mathrm{n}=400 \mathrm{rpm}$ and a full throttle opening $\left(\alpha=90^{\circ}\right)$

Rys. 3. Przykladowe porównanie przebiegów doświadczalnych z modelowymi przy $n=400$ obr/min i petnym otwarciu zaworu klapkowego zespolu przepustnicy $\left(\alpha=90^{\circ}\right)$

$$
\begin{aligned}
& \frac{\mathrm{dp}_{\mathrm{p}}}{\mathrm{dt}}=\frac{\mathrm{kR}}{\mathrm{V}_{\mathrm{p}}}\left(\mathrm{T}_{\mathrm{a}} \dot{\mathrm{m}}_{\mathrm{p}}-\mathrm{T}_{\mathrm{p}} \dot{\mathrm{m}}_{1}-\mathrm{T}_{\mathrm{p}} \dot{\mathrm{m}}_{2}-\right. \\
& \left.-\mathrm{T}_{\mathrm{p}} \dot{\mathrm{m}}_{3}-\mathrm{T}_{\mathrm{p}} \dot{\mathrm{m}}_{4}-\frac{\alpha \mathrm{F}_{\mathrm{p}}(\kappa-1)}{\kappa \mathrm{R}}\left(\mathrm{T}_{1 z}-\mathrm{T}_{\text {sprz }}\right)\right) \\
& \frac{\mathrm{dp}_{\mathrm{zz}}}{\mathrm{dt}}=\frac{\kappa \mathrm{R}}{\mathrm{V}_{1 \mathrm{z}}}\left(\mathrm{T}_{\mathrm{p}} \dot{\mathrm{m}}_{1}-\frac{\alpha \mathrm{F}_{1 \mathrm{z}}(\kappa-1)}{\mathrm{kR}}\left(\mathrm{T}_{1 \mathrm{z}}-\mathrm{T}_{\mathrm{sz} 1}\right)\right) \\
& \frac{\mathrm{dp}_{2 \mathrm{z}}}{\mathrm{dt}}=\frac{\kappa \mathrm{R}}{\mathrm{V}_{2 \mathrm{z}}}\left(\mathrm{T}_{\mathrm{p}} \dot{\mathrm{m}}_{2}-\frac{\alpha \mathrm{F}_{2 \mathrm{z}}(\kappa-1)}{\mathrm{kR}}\left(\mathrm{I}_{2 \mathrm{z}}-\mathrm{T}_{\mathrm{sz} 2}\right)\right) \\
& \frac{\mathrm{dp}_{3 \mathrm{z}}}{\mathrm{dt}}=\frac{\kappa \mathrm{R}}{\mathrm{V}_{3 \mathrm{z}}}\left(\mathrm{T}_{\mathrm{p}} \dot{\mathrm{m}}_{3}-\frac{\alpha \mathrm{F}_{3 \mathrm{z}}(\kappa-1)}{\mathrm{kR}}\left(\mathrm{T}_{3 \mathrm{z}}-\mathrm{T}_{\mathrm{sz} 3}\right)\right) \\
& \frac{\mathrm{dp}_{4 \mathrm{z}}}{\mathrm{dt}}=\frac{\kappa \mathrm{R}}{\mathrm{V}_{4 \mathrm{z}}}\left(\mathrm{T}_{\mathrm{p}} \dot{\mathrm{m}}_{4}-\frac{\alpha \mathrm{F}_{4 \mathrm{z}}(\kappa-1)}{\kappa \mathrm{R}}\left(\mathrm{T}_{4 \mathrm{z}}-\mathrm{T}_{\mathrm{sz} 4}\right)\right)
\end{aligned}
$$

$\dot{\mathrm{m}}_{1 \ldots 4}$ analogically to (1). nimalizację przeprowadzano numerycznie bezgradientową metodą sympleksu Neldera-Meada ${ }^{7}$ aż do osiagnięcia żądanej dokładności obliczeń, przyjętej na poziomie $1 \mathrm{e}^{-6}(5)$, gdzie: $m$ - liczba punktów identyfikowanej krzywej, 1 liczba istotnych współczynników modelu, $\mathrm{p}_{\mathrm{d}}$ - przebieg doświadczalny ciśnienia, $\mathrm{p}_{\mathrm{m}}$ - przebieg modelowy ciśnienia.

Wykorzystując zarejestrowane przebiegi, zmian ciśnień w zbiornikach pomiarowych poszukiwano w kolejnych iteracjach przebiegów modelowych, rozwiązując numerycznie metodą ode $23 \mathrm{tb}^{8)} \mathrm{układ}$ równań różniczkowych (3). Temperaturę gazu w zbiornikach pomiarowych na potrzeby rozwiązania interpolowano metodąjednowymiarową kwadratową, zgodnie z zaleceniem przedstawionym $\mathrm{w}$ pracy [1].

Oceny jakościowej identyfikacji dokonywano przez wyznaczenie błędu średniego, maksymalnego i współczynnika regresji nieliniowej poprawionego na stopnie swobody.

${ }^{7)}$ Minimalizację przeprowadzono z wykorzystaniem pakietu Matlab-Simulink (procedura fminsearch).

8) W terminologii środowiska Matlab-Simulink metoda ode23tb jest połączeniem metody trapezowej z następującą po niej metodą wstecznego różniczkowania drugiego rzędu. 
In paper [12] two different functions of flow intensity have been compared. After an in-depth analysis the most authoritative turned out to be the Miatluka-Avtuszko (4) function with a modified parameter $a=1,07^{5}$ ) [4] (i.e. characterized by the lowest average and maximum error) which was in the extreme case characterized by a 7 times lower error than the permanently applied St' Venant and Wantzel function.

$$
\varphi(\sigma)=\mathrm{a} \frac{1-\sigma}{\mathrm{a}-\sigma}
$$

While searching for the conductance, a method of nonlinear regression was used, minimizing the FPE1 index (5). The minimization was performed numerically through a gradientless method of Nelder-Mead ${ }^{6}$ simplex until the accuracy of the calculations on the level of $1 \mathrm{e}^{-6}$ was reached.

$$
\mathrm{FPE} 1=\frac{\mathrm{m}+1}{\mathrm{~m}(\mathrm{~m}-1)} \sum_{\mathrm{i}=1}^{\mathrm{m}}\left(\mathrm{p}_{\mathrm{d}}-\mathrm{p}_{\mathrm{m}}\right)^{2}
$$

where: $m$ - number of points of the identified curve, 1 -number of significant points in the model, $\mathrm{p}_{\mathrm{d}}$ - experimental course of pressure, $p_{m}$ - model course of pressure.

Using the recorded courses, the authors looked for changes in the pressures in the measurement tanks in the subsequent iterations of the model courses using the ode $23 \mathrm{tb}^{7)}$ system of differential equations (3). The temperature of the gas in the measurement tanks was interpolated by a single dimension square method as per the guidelines in [1].

The qualitative evaluation of the identification was done through determining of the average and maximum error and the coefficient of non-linear regression adjusted to the degrees of freedom.

A coefficient of unevenness of air supply to a combustion engine $\mathrm{QR}$ was proposed.

$$
\mathrm{Q}_{\mathrm{R}}=\frac{\sum_{i=1}^{\mathrm{c}}\left|\mathrm{q}_{\mathrm{i}}-\mathrm{q}_{\mathrm{st}}\right|}{\mathrm{c}}[\%]
$$

where: $\mathrm{q}_{\mathrm{i}}$ - share of individual cylinders in the supply process, $\mathrm{q}_{\mathrm{sr}}$-average share of the cylinder in the supply process of a c-cylinder engine with air.

While analyzing the results of the measurements, the threshold of probability had to be lowered, at which the determined difference in the unevenness of air supply would be significant. This was insomuch important as it allowed a proper determining of the value which, in the final formulation was supported with a probability level at which it was binding.

Comparing the arithmetic averages with the probability of their occurrence (Fig. 4) we can state with the probability

\footnotetext{
5) Originally value $\mathrm{a}=1.13$.

6) The minimization was performed with the use of Matlab-Simulink (fminsearch procedure).

7) In the insider terminology Matlab-Simulink, ode23tb method is a combination of the trapeze method and the subsequent method of second order reverse differentiation.
}

Zaproponowano współczynnik nierównomierności zasilania powietrzem silnika spalinowego $Q_{R}$ określony jako (6),

gdzie: $\mathrm{q}_{\mathrm{i}}-$ udziały poszczególnych cylindrów w zasilaniu, $\mathrm{q}_{\mathrm{sr}}$ - średni udział cylindra w zasilaniu c-cylindrowego silnika powietrzem.

Przy okazji analizy wyników pomiarów pojawiła się konieczność obniżenia progu prawdopodobieństwa, przy jakim wyznaczona różnica nierównomierności zasilania powietrzem będzie istotna. Było to o tyle ważne, iż pozwoliło na poprawne wyznaczenie wartości, która w końcowym sformułowaniu została poparta prawdopodobieństwem, przy jakim obowiązuje.

Zestawiając średnie arytmetyczne z prawdopodobieństwem ich wystąpienia (rys. 4), można z prawdopodobieństwem ok. 49\% stwierdzić, iż sztucznie wywołane zróżnicowanie temperatury ścianek przewodów kolektora dolotowego $\Delta \mathrm{T}=64^{\circ} \mathrm{C}$ zmienia nierównomierność zasilania silnika powietrzem średnio o $6 \% \mathrm{w}$ badanej rozpiętości prędkości (400...2500 obr/min). Analizując jakość identyfikacji (rys. 5), można zauważyć, iż najmniejsze wartości błędów zarówno średniego FPE2, jak i maksymalnego FPE3 dotyczą małych prędkości obrotowych. Błędy rosną wraz ze wzrostem prędkości obrotowej, gdyż intensyfikuje się oddziaływanie zjawisk falowych związanych z częstością i zakłóceniem przepływu strugi wywołanych działaniem rozrządu.

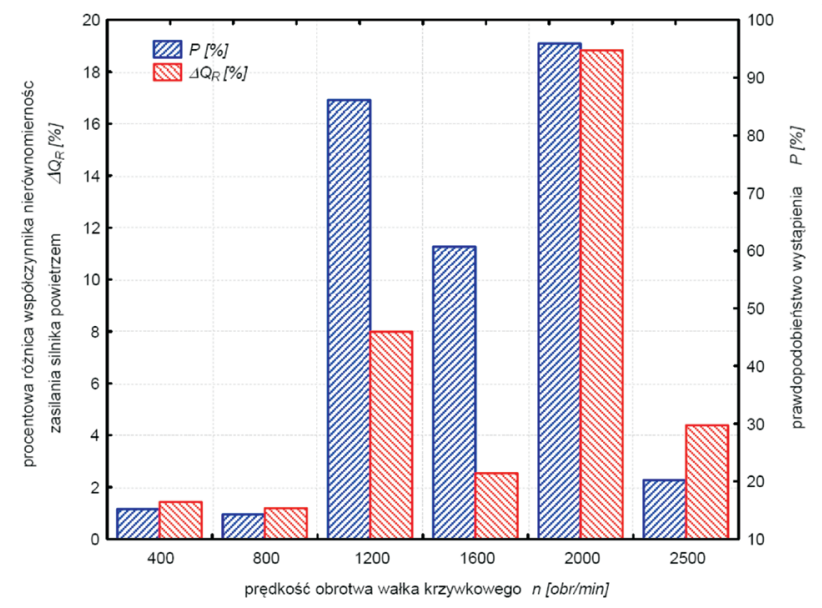

Fig. 4. Percentage difference of the unevenness of supply coefficient $\Delta \theta \mathrm{R}$ and the probability $\mathrm{P}$ of its occurrence in the function of engine speed at full throttle opening

Rys. 4. Procentowa różnica współczynnika nierównomierności zasilania $\triangle \theta R$ i prawdopodobieństwo P jego wystapienia $w$ funkcji prędkości obrotowej, przy petnym otwarciu zaworu klapkowego przepustnicy

Dysponując wynikami identyfikacji z dwóch prób, tj. przeprowadzonej bez zróżnicowania temperatur i z jej zróżnicowaniem, można przedstawić je w formie graficznej z użyciem opcji9" „ramka wąsy” (rys. 6); w tym przypadku wyniki są prezentowane wspólnie dla czterech cylindrów. Jak widać znaczne różnice dotyczą prędkości obrotowej $2500 \mathrm{obr} / \mathrm{min}$ wałka krzywkowego (odpowiada to $5000 \mathrm{obr} / \mathrm{min}$ silnika).

\footnotetext{
9) Wszelkie oceny statystyczne i interpretacje graficzne wykonywano w pakiecie Statistica.
} 
of approximately $49 \%$ that artificial induction of the intake system wall temperature difference $\Delta \mathrm{T}=64^{\circ} \mathrm{C}$ changes the unevenness of air supply by approximately $6 \%$ in the tested engine speed range $(400 \ldots 2500$ $\mathrm{rpm}$ ). Analyzing the quality of identification (Fig. 5) we can notice that the lowest error values of both average FPE2 and the maximum FPE3 pertain to low engine speeds. The error values grow as the engine speed increases because the influence of the wave phenomena intensifies resulting from the frequency and the disturbance of the flow due to the operation of the timing system.

Having the results of the identifications from two trials i.e. with and without temperature differentiation we can show them in a graphic form using the option ${ }^{8)}$ „box-plot” (Fig. 6 ); in this case the results are presented for four cylinders together. As we can see, significant differences are seen at the camshaft speed of $2500 \mathrm{rpm}$ (corresponding to 5000 rpm engine speed).

Simulation tests were instituted as an addition because the experimental research did not yield a clear answer (low threshold of probability) as regards the influence of the thermal state of the intake manifold on the unevenness of the cylinder air filling.

In the first stage of the simulation tests the authors built a virtual model of the stand where the experimental tests were performed. The geometrical characteristics and the initial conditions were in congruence with the real physical counterpart.

The model is simplified, uses the two basic terms assumed in the process of discretization i.e. local resistance and the concentrated volume for which the dependencies (3) and (4) apply. The wave phenomena related to the flow were not taken into consideration. The structure was equipped in a subsystem of ongoing measurement of the heat transfer coefficient and a module determining the time differences of the process of measurement tank filling up to the value of $95 \%$ of the state of saturation. The structural schematics built in Matlab-Simulink has been shown in Fig. 7. The model of the test stand built in such a way allows a continuous tracking of the heat transfer coefficient variations $\alpha$, being a total of forced convection, natural convection and radiation. The forced convection was divided according to the value of the Reynolds number using the Sidler and Tate (laminar range), Żavrankow, Malusova and Małafiejev (transient range) dependences.

The natural convection was to be differentiated depending on the product of the Pr.Gr dimensionless numbers. The initial simulation showed that the said product is of low value, hence the decision to leave one range of values of the heat transfer coefficient which was the result of natural convection.

\footnotetext{
${ }^{8)}$ All statistical evaluations and graphic interpretations have been performed in Statistic.
}

b)

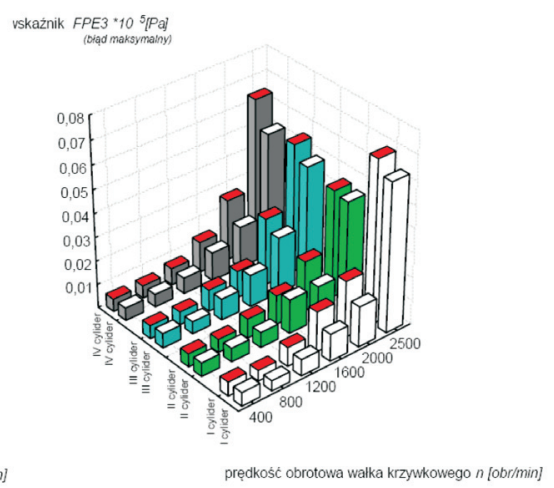

the function of engine speed $\left(\square \Delta \mathrm{T}=0^{\circ} \mathrm{C}, \square \Delta \mathrm{T}=64^{\circ} \mathrm{C}\right)$ $\left(\square \triangle T=0^{\circ} \mathrm{C}, \square \triangle T=64^{\circ} \mathrm{C}\right)$

Z uwagi na to, że badania eksperymentalne nie dały jednoznacznej odpowiedzi (niski próg prawdopodobieństwa), co do wpływu stanu cieplnego układu dolotowego na równomierność napełnienia cylindrów silnika, postanowiono dodatkowo przeprowadzić badania symulacyjne.

W pierwszym etapie badań symulacyjnych zbudowano model wirtualny stanowiska, na którym prowadzono badania eksperymentalne. Zarówno charakterystyka geometryczna, jak i warunki początkowe były zgodne z fizycznym odpowiednikiem.

Model ma charakter uproszczony, wykorzystuje dwa podstawowe człony przyjęte $\mathrm{w}$ procesie dysktretyzacji, $\mathrm{tj}$. opór miejscowy i objętość skupiona, dla których obowiązują zależności (3) i (4). Nie uwzględniono natomiast zjawisk falowych odniesionych do przepływającej strugi. Strukturę wyposażono w subsystem bieżącego wyznaczania współczynnika wnikania ciepła i „moduł” wyznaczania różnic czasowych procesu napełniania zbiorników pomiarowych do wartości $95 \%$ stanu nasycenia ${ }^{10)}$. Schemat strukturalny zbudowany w pakiecie Matlab-Simulink przedstawiono na rys. 7. Tak zbudowany model symulacyjny stanowiska umożliwia śledzenie na bieżąco zmian współczynnika wnikania ciepła $\alpha$, będącego sumarycznym konwekcji wymuszonej, konwekcji naturalnej i promieniowania. Konwekcję wymuszoną podzielono wg wartości liczby Reynoldsa z wykorzystaniem zależności Sidlera i Tate (zakres laminarny), Żavrankowa, Malusovej i Małafiejeva (zakres przejściowy).

Konwekcję naturalną zamierzano zróżnicować w zależności od iloczynu liczb podobieństwa Pr.Gr. Wstępne badania symulacyjne wykazały jednak niewielką wartość tego iloczynu, stąd decyzja o pozostawieniu jednego zakresu wartości współczynnika wnikania ciepła będącego skutkiem konwekcji naturalnej.

Analogicznie do badań eksperymentalnych, w badaniach symulacyjnych zróżnicowano w tym samym zakresie temperaturę ścianek przewodów kolektora dolotowego i poddano analizie te same prędkości obrotowe. Jako kryterium oceny

\footnotetext{
${ }^{10)}$ Przez stan nasycenia rozumie się wartość końcową ustaloną.
} 
a)

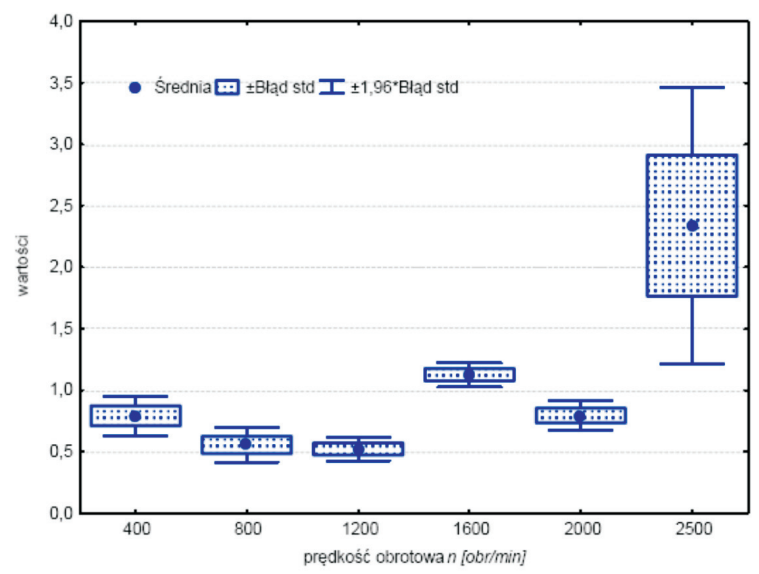

b)

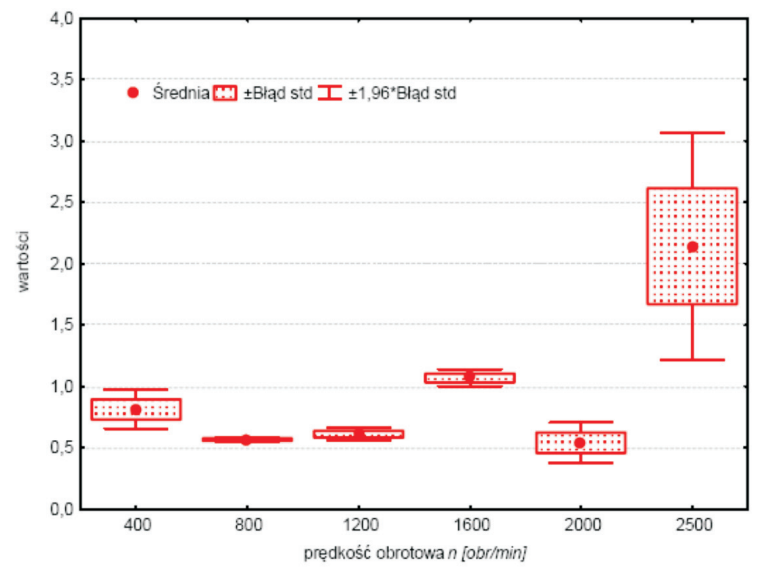

Fig. 6. Graphs ,,box-plot” obtained from the comparison of the averaged values from the trials ( - without differentiation of temperatures , $\square$ with differentiation of temperatures of the intake manifold)

Rys. 6. Wykresy „ramka-wąsy” otrzymane z porównania średnich z prób (- bez różnicowania temperatur, - z różnicowaniem przewodów kolektora dolotowego)

Analogically to the experimental tests, the simulation ones included the differentiation of the temperatures of the intake manifold walls and the same engine speeds were analyzed. As the criterion for the evaluation, the average difference in the filling time up to $95 \%$ of the state of saturation was chosen:

where:

$$
\Delta_{\mathrm{ti}}=\frac{\delta_{\mathrm{i}(\Delta \mathrm{T}=0)}-\delta_{\mathrm{i}(\Delta \mathrm{T}=64)}}{\frac{\sum_{\mathrm{i=1}}^{\mathrm{n}}\left(\delta_{\mathrm{i}(\Delta \mathrm{T}=0)}-\delta_{\mathrm{i}(\Delta \mathrm{T}=64)}\right)}{\mathrm{n}}}[\%]
$$

$$
\delta_{\mathrm{i}(\Delta \mathrm{T}=0)}=\mathrm{t}_{\mathrm{i}(195 \%)}-\mathrm{t}_{\mathrm{i}(\mathrm{III} 95 \%)} \text { and } \delta_{\mathrm{i}(\Delta \mathrm{T}=64)}=\mathrm{t}_{\mathrm{i}(195 \%)}-\mathrm{t}_{\mathrm{i}(\mathrm{III} 95 \%)}
$$

The analysis of the results of the tests shown in Fig. 8 shows that the temperature differences of the walls of the intake manifold $\Delta \mathrm{T}=64^{\circ} \mathrm{C}$ influences the process of the air filling of the measurement tanks. In per cent, the average

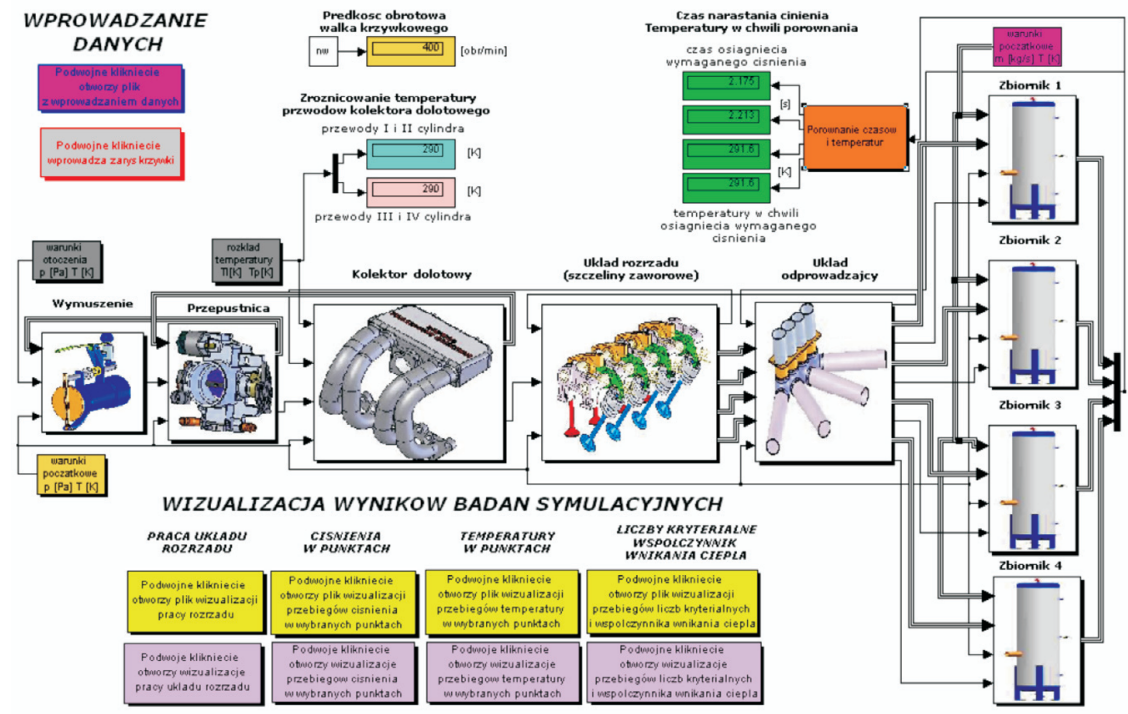

Fig. 7. Structural schematics of the virtual experimental test stand Rys. 7. Schemat strukturalny wirtualnego stanowiska eksperymentalnego poddano średnią różnicę czasów napełniania zbiorników pomiarowych do $95 \%$ stanu nasycenia (7).

Analizując wyniki badań przedstawione na rys. 8, można stwierdzić, iż zróżnicowanie temperatur ścianek przewodów kolektora dolotowego $\Delta \mathrm{T}=64^{\circ} \mathrm{C}$ wpływa na proces napełniania zbiorników pomiarowych powietrzem. Procentowo średnia różnica czasów napełniania $\Delta_{\text {tsr }}=2,7 \%$ względem średniej, przy możliwej maksymalnej wartości $\Delta_{\text {tmax }}=14,2 \%$.

W punktach, w których wyznaczane były czasy osiagania 95\% ciśnienia końcowego ustalanego, wyznaczano również temperaturę powietrza w zbiorniku. Wyznaczając z zależności (7) i (8) różnice temperatur, można stwierdzić średnie zróżnicowanie $\Delta_{\text {T́́r }} \cong 38 \%$ względem średniego, przy możliwym maksymalnym $\Delta_{\text {Tmax }} \cong 95 \%$. Przedstawione wartości odnoszą się do wartości średniej różnic czasowych i temperatur, a obrazują zakłócenie, jakie może wywołać zróżnicowanie temperatury przewodów kolektora dolotowego.

Na podstawie wyników badań z wykorzystaniem modelu symulacyjnego stanowiska eksperymentalnego można stwierdzić, iż wpływ różnicowania temperatury przewodów na czasy napełniania zbiorników powietrzem, jak i zmiany temperatur jest znikomo mały.

\section{Podsumowanie}

Przeprowadzone badania nie pozwalaja jednoznacznie potwierdzić znaczącego wpływu stanu cieplnego układu dolotowego silnika spalinowego na równomierność napełnienia cylindrów powietrzem. Analiza eksperymentalna dowiodła jednak 6-procentowego wpływu, lecz próg prawdopodobieństwa wystąpienia tego zróżnicowania jest znacznie poniżej wartości oczekiwanej (jedynie 48\%). Również badania symulacyjne nie potwierdziły przyjętej hipotezy. 
filling time difference $\Delta_{\text {tśr }}=2.7 \%$ against the average, at the maximum value of $\Delta_{\text {tmax }}=14.2 \%$.

At the points where the times necessary to reach $95 \%$ of the final pressure were determined the temperature of the air in the tanks was determined as well. Determining the differences in the temperatures from the dependence (7) and (8) we can determine the average differentiation $\Delta_{\text {Tśr }} \cong 38 \%$ against the average, at the maximum $\Delta_{\text {Tmax }} \cong 95 \%$. The presented values refer to the average value of the time and temperature differences and depict a disturbance that the temperature difference in the intake ducts may trigger.

Based on the test results with the use of the simulation model of the experimental test stand we can state that the influence of the temperature difference in the ducts on the air filling times and temperature changes is insignificant.

\section{Conclusions}

The performed tests cannot confirm the impact of the thermal state of the intake system on the unevenness of the cylinder air filling. The experimental analysis proved a $6 \%$ influence but the threshold of probability of the occurrence of this difference is way below the expected value (as low as $48 \%$ ). The simulation tests did not confirm this hypothesis either.

Hence, we can finally state that the influence of the thermal state of the intake system on the unevenness of the air supply in the engine may be omitted in the course of the simulation tests of the process of charge exchange. The investigations presented in [12] can confirm this, showing that in a 6-cylinder engine, fitted longitudinally in the vehicle, the temperature difference of the ducts of the intake manifold during the dynamic tests on a chassis dynamometer oscillated around $8^{\circ} \mathrm{C}$ (the tests stand investigations included the difference of $\left.64^{\circ} \mathrm{C}\right)$.

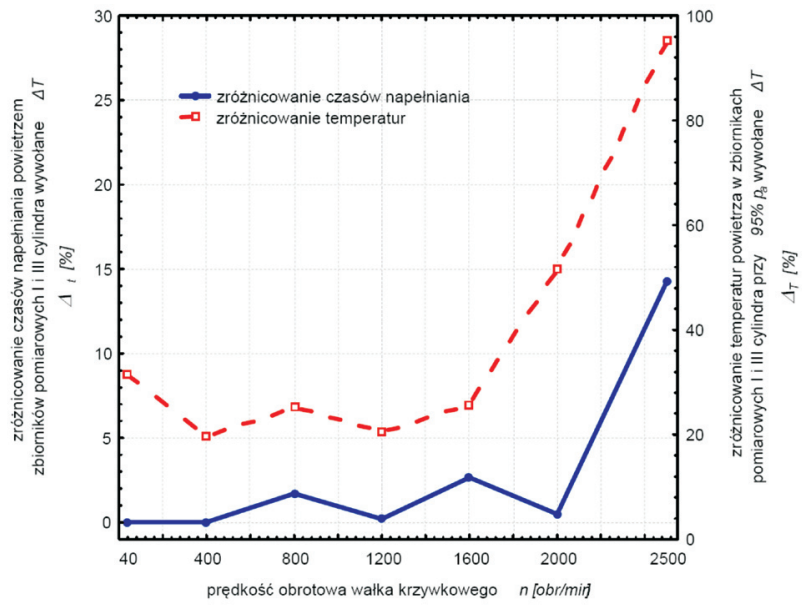

Fig. 8. The influence of the camshaft speed on the percentage variation of the filling time and temperatures in the measurement tanks of the I and III cylinders - simulation tests (full throttle opening)

Rys. 8. Wptyw prędkości obrotowej wałka krzywkowego na procentowe zróżnicowanie czasów napetniania i temperatur powietrza $w$ zbiornikach pomiarowych I i III cylindra - badania symulacyjne (petne otwarcie zaworu klapkowego przepustnicy)

Stąd ostatecznie można stwierdzić, iż wpływ stanu cieplnego układu dolotowego na nierównomierność zasilania silnika może być pomijany w toku badań symulacyjnych procesu wymiany ładunku. Na potwierdzenie tego moga posłużyć badania zawarte w [12], z których wynika, że w silniku 6-cylindrowym zamontowanym w pojeździe wzdłużnie różnica temperatur przewodów kolektora dolotowego, podczas badań dynamicznych na hamowni podwoziowej, oscylowała w granicach $8^{\circ} \mathrm{C}$ (badania stanowiskowe objęły różnicę $64^{\circ} \mathrm{C}$ ).

Artykut recenzowany.

\section{Bibliography/Literatura}

[1] Iwaszko J.: Przepływ sprężonego powietrza przez elementy pneumatyczne połączone szeregowo. Prace Naukowe Instytutu Techniki Cieplnej i Mechaniki Płynów nr 47, Konferencje nr 8, 1994.

[2] Kordziński Cz., Środulski T.: Układy dolotowe silników spalinowych, WKiŁ. Warszawa 1968.

[3] Merkisz J., Gis W., Pielecha J.: Monitorowanie emisji $\mathrm{CO}_{2} \mathrm{i}$ zużycia paliwa w samochodach osobowych. Transport Samochodowy nr 2, Wyd. ITS. Warszawa 2003.

[4] Miatluk M. F., Avtuszko W. P.: Dynamika pnievmatičeskich i gidravličeskich privodov avtomobiliej, Izdatelstwo Maszinostrojenije. Moskva 1980.

[5] Miatluk M., Kamiński Z., Czaban J.: Characteristic features of the airflow of pneumatic elements of agricultural vehicles, Commission of Motorization and Power Industry in Agriculture, vol. 32003.

[6] Mysłowski J.: Doładowanie bezsprężarkowe silników z zapłonem samoczynnym. WNT. Warszawa 1995.

[7] Rawski F.: Określenie parametrów transportu mieszaniny palnej w układzie zasilania silnika spalinowego, przy zastosowaniu techniki izotopowej. Materiały konferencji: Zastosowanie technik radioizotopowych w przemyśle, medycynie i ochronie środowiska, tom I. Warszawa 1998.
[8] Rawski F.: Proces napełniania cylindra przez układ dolotowy silnika tłokowego jako obiekt regulacji, Silniki Spalinowe nr 2, Wyd. Zakładów Przemysłu Metalowego H. Cegielski w Poznaniu. Poznań 1980.

[9] Rawski F., Szpica D.: Równomierność pracy cylindrów silnika spalinowego jako ważny element w zakresie jego ekologii i ekonomii, Archiwum Motoryzacji, vol. 7 nr 2, 2004.

[10] Rawski F., Szpica D.: Wpływ nierównomierności pracy cylindrów silnika spalinowego na emisję toksycznych składników spalin oraz zużycie paliwa, Zeszyty Naukowe Instytutu Pojazdów Politechniki Warszawskiej, z. 4, 2004.

[11] Sobieszczański M.: Modelowanie procesu zasilania w silnikach spalinowych. Zagadnienia wybrane, WKiŁ. Warszawa 2000.

[12] Szpica D.: Badanie procesu zasilania powietrzem cylindrów silnika spalinowego. Rozprawa doktorska, Politechnika Białostocka. Białystok 2005.

Mr Dariusz Szpica, PhD, MEng - doctor in the Faculty of Mechanical Engineering at Białystok University of Technology.

Dr inż. Dariusz Szpica - adiunkt na Wydziale Mechanicznym Politechniki Białostockiej. 